\title{
To Cross the Sexual Borderlands: The History of Sexuality in the Americas
}

Pete Sigal

In 1994, during my final year in graduate school, I decided to teach courses related to the history of sexuality. My agenda was openly political: I wanted students to become more aware of the AIDS pandemic, fight for various sexual freedoms, and oppose the ascendant religious right. I also believed that historians paid far too little attention to issues of sexuality. ${ }^{1}$

The first course I taught, "Queer Bodies/Queer Histories," focused on the ways in which gay, lesbian, bisexual, and transgender identities had been formed historically. The course emphasized the relationship between "queer theory" (see below) and historical discourse. This course went extremely well as students (under half of whom were openly queer) engaged the material in a very exciting way: even "straight" students felt comfortable discussing their own sexual lives and theorizing about how the historical material related to their identities.

Still, the course left me somewhat unsatisfied. I was trained academically as a colonial Latin American historian, but only a small section of the course related to colonial Latin America, and the material for that section was hardly inspiring (it is only recently that early Latin American historians have begun researching sodomy and similar issues). I then taught a course on gender and sexuality in early Latin America. While I believed strongly that students must understand colonialism in 
order to comprehend sexuality in the Americas, I still found myself wondering if the students who did not take both courses would be able to make those connections.

The course went through several incarnations at three institutions before finally, two years ago, I developed a course that resolved some of these issues: "Sexuality in the Americas." My current institution, California State University, Los Angeles, is an urban campus made up primarily of working-class students. About half the students are Latino/a. "Sexuality in the Americas" is an upper-division history course. The students who take it are primarily history and Latin American studies majors, although some students take the course as an elective. Each time the course has been taught, about twenty-five students have enrolled. The diversity of the student body presents many opportunities. Most students in the class had themselves lived in Latin America and/or had family members still living there.

I created this course with the idea of advancing a comparative historical approach. In order for students to understand globalization, imperialism, and colonialism, they must be able to break down the ways in which historical discourse is based on the nation-state. The increasing importance of globalization to the political elite of our society shows just how vital it is for students to be able to understand and challenge this process. As a professor who teaches a student body whose very existence shows that "the border" is not an impermeable physical entity, I believe in the necessity of a political and academic project to challenge that border. Additionally, comparative history is particularly appropriate in the case of sexuality, as it allows students to see various ways in which societies have constructed sexual desires, behaviors, and regulations.

Further, most students have misperceptions about sexuality in both the United States and Latin America. The comparative framework allows me to challenge those misperceptions in a particularly aggressive manner. I think that it is important, even for those teaching the history of sexuality from within a U.S. framework, to emphasize a comparative approach in order to prevent students from believing that people enjoying "sex" is a recent phenomenon that has occurred only in the most Europeanized countries.

The course takes the Americas as a geographical frame of reference set into being through the colonization of indigenous societies by Europeans. The course begins by analyzing sexuality in early modern Europe, Africa, and the Americas before the conquest. I then move to a discussion of conquest itself, and particularly I relate warfare to the sexual symbolism that Europeans and many indigenous Americans saw as implicit within the events. The next section analyzes colonialism and the changes in sexual norms that took place as a result of the power dynamics and ethnic mixtures involved in colonial rule. An early lecture on this topic, based partly on Ramón Gutiérrez’s When Jesus Came, the Corn Mothers Went Away, begins to challenge students' perceptions of ethnic and sexual borders. Next, the course moves for- 
ward through the early national period, again asking the students to understand the sexual imagination as it played a role in the development of nation-states.

At this point in history, the nation-state became an important barometer for understanding the formation of sexuality, but my approach to the course purposely goes beyond the nation-state. In order to resolve this problem, I begin to focus on specific issues within a national context, and then I develop comparisons. So, for example, I take the United States as the basis for an analysis of the eugenics movement, comparing Argentina, Mexico, and Brazil where relevant.2 Students discover that the United States was a bastion for many of the worst racial ideologies associated with this movement but that the Latin American countries were not exempt from such thinking.

In another lecture, I take Brazil as the model for an analysis of the development of gay communities in the early twentieth century, comparing these communities with those of the United States. Using Brazil instead of the United States as the primary model shocks students, who often seem to believe that the United States "exported" homosexuality to Latin America. Similarly, when I discuss prostitution, I focus on Argentina; when I discuss the sexual symbolism of the state, I focus on Mexico; and when I discuss the relationship between sexuality and revolution, I focus on Cuba and Nicaragua, always being sure to foreground the comparative approach.

\section{Theoretical Issues}

When I first proposed teaching the course, my main academic goal was to force students to think about the complexity of identity construction. The counterintuitive notion promoted by social constructionist theory, that biology does not produce identity, has much radical potential. At some point in the course, students begin to conceive of identity as an entity possessing sociopolitical meaning. They begin to understand that different societies have constructed identities in different ways, and that a society's construction of identity can be challenged. But, for students heavily invested in identity, social constructionism is a very difficult concept to grasp. So I spend much of the term working on historical constructions, and I only challenge their own identities as an end result of the historical logic imposed by the course.

My lectures are informed particularly by theoretical material from people who have been identified as queer theorists, such as Leo Bersani, Judith Butler, Michel Foucault, and Gayle Rubin. These theorists, while they vary in their approaches, have argued that the basic categories of heterosexuality and homosexuality are constructs and that we perform our identities in our everyday activities. In the classroom, the theories lend themselves to a historical approach, for most students do not take well to direct challenges to their identities. Yet they are able to understand the argument that different societies have different sexual constructs. So, 
for example, I am able to use historian Richard Trexler's critique of essentialism in Sex and Conquest: Gendered Violence, Political Order, and the European Conquest of the Americas to get students to understand the ways in which indigenous societies constructed masculinity and femininity. Similarly, James Green's understanding of identity in Beyond Carnival: Male Homosexuality in Twentieth-Century Brazil shows students that even modern homosexual identities are complex and varied.

Lectures based on these and other works help students understand sociohistorical constructions of sexuality, but reading Gloria Anzaldúa’s Borderlands/La Frontera: The New Mestiza brings the concept home for many students. Anzaldúa argues, using essays and poetry, that we are living in a sexual/gender/ethnic/national borderland and that, because of this, our identities are in flux. With such a reading, I structure a discussion during which students, although resistant, begin to question their own ethnic and sexual identities. Anzaldúa's poetry allows them to see the connections between identity, culture, and history in a particularly vivid way.

\section{Assignments}

The syllabus is the first reading assignment. I demand that students take the syllabus home and read the course description very carefully. The extended essay that begins the syllabus, and the questions throughout it, are intended to provoke. When students come to the second day of class, they have often read the syllabus, shown it to friends and family, laughed and/or gotten angry about it, and, most importantly, thought about some of the issues raised. I find this exercise more useful than a lecture, as students are able to reflect on the concepts presented and come to class interested and prepared.

The other readings assigned for the course range from a textbook on the history of sexuality in the United States (John D'Emilio and Estelle Freedman's Intimate Matters: A History of Sexuality in America), three collections of essays, Anzaldúa's book, and other relevant articles. I also provide students with short primary sources that they read and analyze during class. The textbook provides students with a strong overview, but it only covers the United States and necessarily leaves out many issues. Both Merrill Smith's Sex and Sexuality in Early America (that deals mostly with North America) and Lyman L. Johnson and Sonya LipsettRivera's The Faces of Honor: Sex, Shame, and Violence in Colonial Latin America (that deals with colonial Latin America) cover many provocative topics and allow students to realize that their early ancestors really did have sex! Both books analyze indigenous, African, and European societies, and the Latin American collection in particular discusses ethnic mixture. Daniel Balderston and Donna Guy's Sex and Sexuality in Latin America covers the modern period and provides both literary and historical approaches to the study of sexuality. 
Students often identify most with the primary sources, as these allow them to see people struggling with their own sexual desires. Some of the sources show the students that people have engaged in all kinds of sexual acts for a long time, and others show them that states have attempted to regulate sex for just as long.

Students are required to write two papers and finish a group project. The first paper focuses on the connections between culture, colonialism, and sexuality. I ask them to incorporate many of the readings from the two collections. They provide historiographical critiques of these readings. The second paper is a research paper in which students combine a small number of primary and secondary sources to develop an argument about an issue of their choice. Students often have difficulty with the first paper because the topic is new to many of them, and they find it hard to critique the arguments. The second paper allows for more variety, but it requires me to give them significant direction in locating appropriate sources.

The group projects are the most fun for me. Students, in groups of about five, are required to pick a topic, do the research, and present the topic to the entire class. They are required to present their topic in a creative manner, and I refuse to place any limits (beyond those required by law) on their creativity. Among other things, I have seen a movie recreating nineteenth-century romantic friendships, a play about pornography, a skit on prostitution in Mexico, and a demonstration of genital piercing. In the play about pornography, for example, the students played people employed in various sectors of the industry as well as people engaged in debates regarding the issue. They historicized the debates by representing pornographic scenes and debates from various different eras. When the students become fascinated with the topic and strongly engage their own creative energies, they produce the best projects.

The student evaluations are consistently among the best I get for any course. Most students particularly like the lively discussions and the group projects. A minority of students, however, do not like these projects, and they want more direction than I, in my effort to encourage creativity, am willing to provide. Other students like the fact that I am up-front about my political and academic goals for the course and that I discuss sexuality in a frank way. Some students come to me during or after the course to tell me about the personal effects that the course has had on them. Survivors of domestic violence have told me that the course helped them confront their past. Queer students have told me that the course helped them "come out of the closet." Other students have come to me in tears to discuss various personal issues having to do with sex. While many of these students have affirmed my reasons for teaching the course, I also have felt frustrated that I am unable to help some of them. 


\section{Reflections}

The course has allowed me to combine my interest in questions of cultural colonization with the history of sexuality. More strongly than in other courses on the history of sexuality that I have taught, students come out of this course understanding both the politics of sexuality and the social construction of sexual identity. Such a result emanates from the comparative approach. When comparing different countries, students are better able to grasp the ways in which culture, society, ethnicity, class, gender, and the nation-state affect sexual constructions. Students see quite vividly the politics behind particular policies related to sexuality, and they see how cultural issues are reflected in the various policies. They then move from there to a greater understanding of social constructs. They see that meaning is established in different ways based on the cultural notions in play at a particular place and time. Thus I find the comparative approach critical.

However, as many others have noted, historians are wedded to the nationstate. In fact, at California State University, Los Angeles, there was some resistance to my teaching a course that goes beyond the geographic region of Latin America. History students who take this course can only credit it toward their Latin American history requirement, not their United States history requirement, thus limiting the students who will enroll. Further, the institution gives students so few electives that most students who are not history or Latin American studies majors find that they cannot fit the course into their programs. If these regulations were altered, students with a wider diversity of interests could take the course and benefit from the subject matter and the critical pedagogy. I believe that the difficulties of organizing such a cross-nation course are far outweighed by the advantages.

I am considering changing the readings for the next time I teach the course. As students respond particularly effectively to the personal narrative of Anzaldúa, I probably will include a few more historical/personal accounts. I might include such things as diary entries from nineteenth-century women in the United States, Mexican Inquisition cases, and testimonies from Brazilian transvestites. I also found students overwhelmed by some of the literary theory in a few of the articles, so I may change some of those to more historically oriented texts.

Additionally, I have found that, as the course focuses primarily on cultural and social issues, I have lost track of some of the initial policy implications. I plan to reorganize the time spent in the course to focus more attention on the historical relevance of issues such as AIDS, abortion, pornography, the sexual abuse of children, and gay rights. Various lectures can be changed to make a more explicit connection between earlier historical issues and contemporary policies.

With these changes, students will come out of the course with a greater understanding of the implications of the theoretical approach on both a personal and a political level. In order for students to critically question issues related to sexual 
identity, they must understand the social, cultural, and historical dimensions of sexuality. When we see a new Republican administration that, in one of its first acts, restricts family-planning funding to exclude organizations that use their own money to perform or discuss abortion, the importance of this course could not be more clear.

\section{SEXUALITY IN THE AMERICAS}

\section{California State University, Los Angeles}

I am my mother's lover. The partner she's been waiting for.

- Cherríe Moraga

In their zeal to protect fetal life at all costs, anti-abortionists are ready to grant fetuses more legal protection than people.

—Ellen Willis

This is not new.

Colored, poor, latent queer

passing for white

seething with hatred, anger

unaware of its source

crazed with not knowing

who they are

choose me to pick at the masks.

— Gloria Anzaldúa

The time has come to think about sex. To some, sexuality may seem to be an unimportant topic, a frivolous diversion from the more critical problems of poverty, war, disease, racism, famine, or nuclear annihilation. But it is precisely at times such as these, when we live with the possibility of unthinkable destruction, that people are likely to become dangerously crazy about sexuality. Contemporary conflicts over sexual values and erotic conduct have much in common with the religious disputes of earlier centuries. They acquire immense symbolic weight. Disputes over sexual behavior often become the vehicles for displacing social anxieties, and discharging their attendant emotional intensity. Consequently, sexuality should be treated with special respect in times of great social stress.

The realm of sexuality also has its own internal politics, inequities, and modes of oppression. As with other aspects of human behavior, the concrete institutional forms of sexuality at any given time and place are products of 
human activity. They are imbued with conflicts of interest and political maneuvering, both deliberate and incidental. In that sense, sex is always political. But there are also historical periods in which sexuality is more sharply contested and more overtly politicized. In such periods, the domain of erotic life is, in effect, renegotiated.

—Gayle Rubin

And so the story goes. Through this course, we use these renegotiations to weave an understanding of the history of sexuality. But what is sexuality? Can we even know what the topic is that we intend to study? We don't know these answers yet, and we probably never will.

Is sexuality our use of genitals? Is it our understanding of pleasure? Or danger? Or pain? Is it some political terrain, a fight between men and women? Is it even a "thing" that can be demarcated? Is it what we don't talk about?

How can we discuss what we don't discuss? How can we talk about what we don't talk about? I intend the course for people who can discuss complex and controversial subject matter in a mature fashion. We will be theoretical, yet we will be sexually explicit.

Sexuality: Everybody knows what it is, yet nobody can define it. Seems silly, doesn't it?

As Gayle Rubin points out, sexuality is contested terrain. Sexuality changes through time and through cultures and classes and races and genders and geographic areas and families and individuals and. . . .

Sexuality relates to religion:

La luna me chupa

mi sangre

inhales, exhales

and ventures

to the six directions.

I bleed a pleasurable pain.

I do not doubt

that Christ died on the cross

with nails in palm

and if it were for

my sins to come,

I thank her.

—Cathy Arellano

Or it relates to the centrality of self-definition:

Definitions have their uses in much the same way that road signs make it easy to travel: they point out the directions. But you don't get where you're going when you just stand underneath some sign, waiting for it to tell you what to do.

- Kate Bornstein 
Well then maybe this course should go beyond the study of the street sign. And maybe we cannot define sexuality any more than any but the most old-fashioned historian can define history. Here we will tell stories and try to define a topic. We will find the ways in which different societies have defined this topic for themselves. And we will perhaps begin to see the ways in which sexuality and history itself are formed.

\section{Readings}

Gloria Anzaldúa, Borderlands/La Frontera: The New Mestiza (San Francisco: Aunt Lute, 1987).

Daniel Balderston and Donna J. Guy, eds., Sex and Sexuality in Latin America (New York: New York University Press, 1997).

John D’Emilio and Estelle Freedman, Intimate Matters: A History of Sexuality in America (New York: Harper and Row, 1988).

Lyman L. Johnson and Sonya Lipsett-Rivera, eds., The Faces of Honor: Sex, Shame, and Violence in Colonial Latin America (Albuquerque: University of New Mexico Press, 1998). Merril D. Smith, ed., Sex and Sexuality in Early America (New York: New York University Press, 1998).

Course Reader

\section{Writing Assignments}

1. 10 percent: In-class assignments (including any quizzes) and participation. You will have a series of in-class assignments done by yourself or in groups. These assignments were designed in order to encourage active learning. They will incorporate your ability to analyze meanings presented in documents, to find the theses of articles and lectures, and to interpret and apply theoretical material. In most cases you will not be told ahead of time when an in-class assignment will take place. If you miss class on that day, you will get a "o" for the assignment. No make-ups will be given.

2. 20 percent ( 15 percent for graduate students): Group Project. At the first class meeting, we will divide into groups. Your group will be responsible for covering a particular topic in class and coming up with a creative way to discuss the chosen topic. Your grade will be based on the creativity of your presentation and the thoroughness of your research.

3. 20 percent ( 15 percent for graduate students): A four-to-five-page paper on culture, colonialism, and sexuality (due on January 31 ).

4. 25 percent (20 percent for graduate students): A four-to-five-page research paper on a topic you choose (due on March 5 ).

5. 25 percent (2o percent for graduate students): A take-home final examination.

6. Graduate students (2o percent): All graduate students are required to meet with the instructor within the first two weeks of the quarter. It is your responsibility to arrange this meeting. In addition to the other requirements, you will be required to write an analytical book review (four to five pages in length) of an additional book.

You will be penalized for assignments handed in late. 


\section{COURSE SCHEDULE}

January 3: Sex and Theory I: The Essentials, The Constructed Questions:

1) What is sex? 2) Is sex repressed? 3) What is sexuality? 4) How is it invented? 5) How is it changed through time? 6) What is biology? 7) What is the human body? 8) What is gender?

\section{January 8: Sex, Power, and Desire before the Conquest}

\section{Readings}

Intimate Matters, chapter 1; Cecelia Klein, "Fighting with Femininity: Gender and War in Aztec Mexico" Estudios de Cultura Náhuatl 24 (1994): 219-53; Richard C. Trexler, "Gender Subordination and Political Hierarchy in Prehispanic America," in Infamous Desire: Male Homosexuality in Colonial Latin America, ed. Pete Sigal (Chicago: University of Chicago Press, forthcoming).

\section{Questions}

1) What is sexuality to non-Western societies? 2) How does it relate to power here? 3 ) Do these societies regulate sexual behavior? 4) Was sexuality less regulated in these societies? 5) How did Native American societies understand homosexuality? 6) What was the berdache? 7) Did the berdache change historically? 8) How did the berdache relate to these societies politically? 9) How did Nahua society relate gender to sexuality? 10) What is the relationship between this and power? 11) How did the Maya understand sexual behavior? 12) How does this relate to the West's understanding of sexuality?

\section{January 10-17: North American Colonization}

(No class January 15)

\section{Readings}

Intimate Matters, chapters 2-3; Sex and Sexuality in Early America.

\section{Questions}

1) How is sexuality related to colonization? 2) How did the British relate sexuality to their colonial experiences? 3) How did they relate sexuality to their missionary work? 4) How does colonization affect the sexuality of the colonizers?

\section{January 22-24: Honor and Desire in Colonial Latin America \\ Readings}

The Faces of Honor

\section{Questions}

1) How does Spanish colonization relate to sexuality and gender? 2) How does conquest relate to sexuality? 3) How do we see culture renegotiated? 4) How does the colonial North American system differ from Latin America? 
January 29: Witchcraft and Sexual Magic

Readings

Ruth Behar, "Sex and Sin: Witchcraft and the Devil in Late Colonial Mexico," American Ethnologist 14 (1987): 34-54; Irene Silverblatt, "Andean Witches and Virgins: SeventeenthCentury Nativism and Subversive Gender Ideologies," in Women, "Race," and Writing in the Early Modern Period, ed. Margo Hendricks and Patricia Parker (London: Routledge, 1994), 259-271

\section{Questions}

1) How do sexuality and magic relate? 2) How do we see sexuality reconstructed to make sense of history? 3) How does witchcraft relate to sexuality? 4) How does this sense of sexuality relate to gender? 5) Does colonization relate to sexual mixture and race mixture?

January 31: Victorian Desires and the Birth of the Nation-State

Readings

Intimate Matters, chapters 4, 6-7; Deena F. Gonzalez, "La Tules of Image and Reality," in Building with Our Hands: New Directions in Chicana Studies, ed. Adela de la Torre and Beatríz M. Pesquera, (Berkeley: University of California Press, 1993), 75-9o.

\section{Questions}

1) How do symbols of nation and symbols of sexuality connect with each other? 2) What are our notions of Victorian sexuality? 3) How do these notions change through the readings? 4) Was Victorian sexuality repressed? 5) How did Victorian sexuality relate to class and gender?

\section{February 5: The Sexuality of Slavery}

\section{Readings}

Intimate Matters, chapter 5; Rennie Simson, "The Afro-American Female and the Historical Context of the Construction of Sexual Identity," in Powers of Desire: The Politics of Sexuality, ed. Ann Snitow, Christine Stansell, and Sharon Thompson (New York: Monthly Review, 1983), 229-235; Jacquelyn Dowd Hall, "The Mind that Burns in Each Body," in Powers of Desire, $328-349$.

\section{Questions}

1) How do African Americans make sense of sexual colonization? 2) How does race relate to sexuality? 3) Why is slavery related to sexual conquest? 4) How does slavery relate to our notions of rape? 5) How does sexuality relate to the Civil War? 6) Why would our image of Reconstruction be loaded with sexual ideas? 7) Why do historians not recognize the sexuality implicit in Reconstruction? 8) How does lynching become a sexual act? 
February 7: The Invention of Sexuality: From Eugenics Movements to Social Purity Readings

Intimate Matters, chapters 8-10; Sex and Sexuality in Latin America, chapters 5-6; Ellen Carol DuBois and Linda Gordon, "Seeking Ecstasy on the Battlefield," in Pleasure and Danger: Exploring Female Sexuality, ed. Carole S. Vance (London: Pandora, 1989), 31-50.

\section{Questions}

1) Why would sexuality be a central issue at the end of the nineteenth century? 2) How is sex itself invented during this time period? 3 ) What do the sexologists have to say about this? 4) How will this relate to Freud? 5) How do passing women relate to socioeconomic class? 6) How do they alter ideas of gender? 7) How do they relate to sexuality? 8) What does social purity have to do with sexuality? 9) Why did women become so politically active against sexual freedoms? 10) How does this relate to prostitution? 11) How does it relate to the invention of the homosexual? 12) When will the heterosexual be invented? 13) What is eugenics?

\section{February 12: Modernity and Sexuality \\ Readings}

Sex and Sexuality in Latin America, chapters 7, 10-11; Kathy Peiss, "Charity Girls and City Pleasures," in Powers of Desire, 74-87; Hazel Carby, "It Just Be Dat Way Sometime," in Unequal Sisters: A Multicultural Reader in U.S. Women's History, ed. Ellen DuBois and Vicki Ruiz (New York: Routledge, 1990), 238-49.

\section{Questions}

1) How is gender being performed in the various articles? 2) How does sexuality move from the working class to the middle class? 3) Why is Harlem so sexual? 4) What does Harlem represent racially and sexually? 5) How does this relate to the blues? 6) What does drag have to do with class and sexuality? 7) What does it mean as we see drag performed before gay liberation?

\section{February 14: Birth Control and the New Woman \\ Readings}

Intimate Matters, chapter 11; Linda Gordon, "Birth Control and Social Revolution," in Woman's Body, Woman's Right: A Social History of Birth Control in America (New York: Grossman, 1976).

\section{Questions}

1) Who was the New Woman? 2) Why is abortion such a debate? 3) How does it relate to the birth control debates? 4) Why were any of these debates at all? 5) How does religion relate to the debate? 6) Why does birth control become legalized? 7) Why does abortion become legalized? 8) How do these rights protect women? 9) Why do the debates rage on? 


\section{February 19: Sexuality and the Formation of the State}

\section{Readings}

Sex and Sexuality in Latin America, chapter 8; Ana María Alonso, "Gender, Power, and Historical Memory," in Feminists Theorize the Political, ed. Judith Butler and Joan Scott (New York: Routledge, 1992); Marjorie Becker, “Torching La Purísima, Dancing at the Altar: The Construction of Revolutionary Hegemony in Michoacán, 1934-1940," in Everyday Forms of State Formation: Revolution and the Negotiation of Rule in Modern Mexico, ed. Gilbert M. Joseph and Daniel Nugent (Durham, NC: Duke University Press, 1994), 247-64.

\section{Questions}

1) How do sodomy, incest, and virginity relate to the creation of the State? 2) What does this tell us about the political power of sexual desire? 3) How does historical memory relate to sexuality? 4) How do political officials attempt to use sexuality to form a particular version of politics? 5) How does this relate to the Catholic Church's use of sexuality?

\section{February 21: The Invention of Feminism}

Readings

Borderlands, 1-49; Sex and Sexuality in Latin America, chapter 11; Intimate Matters, chapters 12-14; Alice Echols, "The New Feminism of Yin and Yang," in Powers of Desire, $439-59$.

\section{Questions}

1) Why is the feminist movement formed in the late twentieth century? 2) How does feminism understand sexual desire? 3) What does the feminist movement have to do with sex? 4) How are race and ethnicity related to feminism?

\section{February 26: The Invention of Gay and Lesbian Identity}

\section{Readings}

Sex and Sexuality in Latin America, chapters 2, 4, 8, 12, 16; John D’Emilio, "Gay Politics and Community in San Francisco since World War II," in Hidden from History: Reclaiming the Gay and Lesbian Past, ed. Martin Duberman, Martha Vicinus, and George Chauncey Jr. (New York: NAL, 1989), 153-68.

\section{Questions}

1) Why did the gay movement start when it did? 2) How does gay and lesbian identity relate to the military? 3) How does this relate to us today? 4) How does this identity relate to ethnicity and culture? 5) How does a gay movement deal with these different cultures? 6) How does it relate internationally? 7) Why did the gay movement break apart? 8) How did this movement relate to drag queens and butch/femme women? 9) What did this mean for the free love movement? 
February 28-March 5: Sexual Danger v. Sexual Pleasure

Readings

Borderlands, 50-138; Sex and Sexuality in Latin America, chapter 3; Ellen Willis,

"Feminism, Moralism, and Pornography," in Powers of Desire, 46o-6; Amber Hollibaugh and Cherríe Moraga, "What We're Rolling around in Bed With," in Powers of Desire,

$394-405$.

\section{Questions}

1) How does childhood sexuality relate to rape? 2) Why are women raped? 3) How does it relate to sexuality, violence, and power? 4) Why are men raped? 5) Why has rape become such a central issue in the lives of women? 6) Has this changed historically? 7) How have feminists argued against rape? 8) How have they prevented it? 9) Does sexual harassment have to do with culture? 10) What do these issues have to do with machismo? 11) Why do some feminists want to restrict pornography? 12) What does this have to do with their own internal sexual debates? 13) How could pornography be banned? Should it be? 14) How do incest and child pornography relate to these debates?

\section{March 7: AIDS and Sexuality}

Readings

Intimate Matters, chapter 15; Alberto Sandoval, "Staging AIDS: What's Latinos Got to Do with It?” in Negotiating Performance: Gender, Sexuality, and Theatricality in Latin/o America, ed. Diana Taylor and Juan Villegas (Durham, NC: Duke University Press, 1994), 49-66; Cindy Patton, "Germphobia" and "Identity and Community," in Sex and Germs: The Politics of AIDS (Boston: South End, 1985), 51-67, 119-33.

\section{Questions}

1) How does AIDS permanently alter U.S. culture? 2) How will this work in Latin America?

3) How does AIDS repoliticize gay men? 4) How is AIDS figured in the media? 5) How does a disease turn into a representation of a person? 6) How does AIDS discriminate? 7) How are safe-sex campaigns worked? 8) Who promotes safe sex? 9) Who opposes all safesex efforts? Why? 10) How does the government respond? 11) Who forces the government's hand? 12) Who's now most likely to get AIDS?

\section{March 12: Sex and Theory II: The Borderlands \\ Readings}

Borderlands, 139-203

\section{Questions}

1) What is postmodern sexuality? 2) How does this relate to the quest for the borderlands?

3) How does it relate to gender transformation? 4) Where does sexuality come in to this quest? 5) What does this tell us about our future? 


\section{Notes}

I would like to thank Cheryl Koos, Enrique Ochoa, Heidi Tinsman, and Lillian Taiz for comments on a previous version of this article.

1. Previously I had worked with Ellen DuBois, and I helped her create a course on the history of sexuality that we co-taught in 1992.

2. Of course, I can only accomplish this task when pertinent documents are available. 